\title{
The activity and kinetic properties of cellulases in substrates containing metal ions and acid radicals
}

\author{
Ge Wang ${ }^{1,2}$, Xiaowen Zhang ${ }^{1}$, Li Wang ${ }^{1}$, Keke Wang ${ }^{1}$, Fanglin Peng ${ }^{1}$, Linsong Wang ${ }^{1 *}$ \\ ${ }^{1}$ College of Life Science, Henan Normal University, Xinxiang, China \\ ${ }^{2}$ Department of Basic Medicine, Xinxiang Medical College, Xinxiang, China \\ Email: ${ }^{*}$ wls@htu.cn
}

Received 6 August 2012; revised 15 September 2012; accepted 21 September 2012

\begin{abstract}
The effects of various metal ions $\left(\mathrm{Na}^{+}, \mathrm{K}^{+}, \mathrm{Ca}^{2+}, \mathrm{Mg}^{2+}\right.$, $\left.\mathrm{Al}^{3+}, \mathrm{Co}^{2+}\right)$ and anions $\left(\mathrm{Cl}^{-}, \mathrm{SO}_{4}^{2-}\right.$ and $\left.\mathrm{CH}_{3} \mathrm{COO}^{-}\right)$on two cellulases were investigated. Fitting of the data to Michaelis-Menten kinetics showed that $\mathrm{Al}^{3+}$ noncompetitively inhibited cellulase $\left(K_{m}=22.68 \mathrm{~g} / \mathrm{L} ; V_{\max }=\right.$ $0.269 \mathrm{mg} / \mathrm{min}$ at $\left.5.0 \mathrm{mmol} / \mathrm{L} \mathrm{AlCl}_{3}\right)$ and $\mathrm{Mg}^{2+}$ competitively inhibited cellulase $\left(K_{m}=50.0 \mathrm{~g} / \mathrm{L} ; V_{\max }=\right.$ $0.434 \mathrm{mg} / \mathrm{min}$ at $10.0 \mathrm{mmol} / \mathrm{L} \mathrm{MgCl}_{2}$ ) Different metal ions increased or decreased inhibition of cellulase activity slightly below $1 \mathrm{mmol} / \mathrm{L}$ and strongly over 10 $\mathrm{mmol} / \mathrm{L}$. The results indicated that filter paper activeity (FPA) was suitable for analysis of enzymatic saccharification with various lignocellulosic substrates whereas crude cellulase was suitable for applications in the biomass industry. Some metal ions were proved to inhibit cellulase reversibly.
\end{abstract}

Keywords: Cellulase; Enzyme Activity; Enzyme Deactivation; Kinetics Parameters; Metal Ions; Anions

\section{INTRODUCTION}

Cellulases are widely used in biotechnology and industry [1-3]. Additionally, cellulase plays central roles in the bioconversion of renewable cellulosic biomass to commodity chemicals $[4,5]$. Due to increasing concern for the greenhouse effect, depleting oil reserves and skyrocketing oil prices, as well as interest in renewable fuels, such as bioethanol, cellulases are increasingly becoming important for contributing to the green environment. Therefore, many efforts have been made to transform various cellulosic biomasses into fermentable sugar using cellulases for further conversion to ethanol, which is the most common renewable fuel so far [6].

There are two kinds of commercial cellulases, crude and pure enzymes. The crude one constitutes a complete enzymatic system and contains usually three enzymes

"Corresponding author. that act synergistically in the hydrolysis of cellulose: endoglucanase (EG, EC 3.2.1.4), cellobiohydrolase (CBH, EC 3.2.1.91) and cellobiase ( $\beta$-glucosidase, EC 3.2.1.21). The first two enzymes in this category act directly on cellulose, yielding mainly cellobiose and glucose as reaction products, and then the cellobiose is hydrolyzed into glucose by cellobiase $[3,6]$. Although the crude cellulase has a lower specific activity than pure cellulase containing only one of the enzymes described above, it is still used in many fields such as animal feed and industrial ethanol production because of its cheapness [7]. The pure one is more used in laboratory to analyze its character.

The bioconversion process typically involves the three steps of pretreatment, hydrolysis, and fermentation. A number of different pretreatment methods have been developed, which include organosolve, dilute-acid, dilute-base, and $\mathrm{SO}_{2}$-catalyzed steam explosion and so on. Current research on cellulase hydrolysis is mainly focused on characterization of cellulases. Mawadza et al. [8] reported that metal ions $\mathrm{K}^{+}, \mathrm{Na}^{+}, \mathrm{Mg}^{2+}, \mathrm{Cu}^{2+}$, $\mathrm{Ca}^{2+}, \mathrm{Ni}^{2+}, \mathrm{Zn}^{2+}$ and $\mathrm{Fe}^{3+}$ had little effect on the activity of cellulase at $1 \mathrm{mmol} / \mathrm{L}$ whereas the effect of $\mathrm{Co}^{2+}$ was significant at the same concentration. Cellulase activity was inhibited by $10 \mathrm{mmol} / \mathrm{L}$ of $\mathrm{Cu}^{2+}, \mathrm{Zn}^{2+}, \mathrm{Co}^{2+}$ or $\mathrm{Pb}^{2+}$ when carboxymethyl cellulose (CMC) was used as substrate [9]. In addition, heavy metal or transition metal ions, notably $\mathrm{Ag}^{+}, \mathrm{Hg}^{2+}$ and $\mathrm{Mn}^{2+}$ showed a tendency to inhibit cellulase activity [10]. Natrium, potassium and acetate were used in buffer solutions suitable for cellulase reaction $[7,11]$. Although a number of studies have been focused on the role of metal ions and anions on cellulase, few studies were related to the relationship between ionic concentrations and enzymatic kinetics. In fact, many metal ions and anions with different concentrations are used in the industry. The enzyme dosage was $10 \mathrm{FPU} / \mathrm{g}$ water-insoluble substances to $40 \mathrm{FPU} / \mathrm{g}$ water-insoluble substances in an enzymatic prehydrolysis prior to simultaneous saccharification and fermentation. Other enzyme reaction factors were $\mathrm{pH} 4.8$ to 
$6.0,0.05 \mathrm{~mol} / \mathrm{L}$ to $0.5 \mathrm{~mol} / \mathrm{L}$ citrate or acetate buffer solution, $40^{\circ} \mathrm{C}$ to $52^{\circ} \mathrm{C}$, solid substrate concentration of 80 to $110 \mathrm{~g} / \mathrm{L}$ and the final concentrations of $0.5 \mathrm{~g} / \mathrm{L}$ $\left(\mathrm{NH}_{4}\right)_{2} \mathrm{HPO}_{4}, 0.025 \mathrm{~g} / \mathrm{L} \mathrm{MgSO}{ }_{4} \cdot 7 \mathrm{H}_{2} \mathrm{O}$ and $1.0 \mathrm{~g} / \mathrm{L}$ yeast extract in the fermenter $[3,4,7,8,11]$. The concentration of ions and chelating agents would play an essential role in the biomass industry when the effect of metal ions and anions on cellulase varied significantly with their concentrations. In the present study, the effects of these metal ions and anions on crude or purified cellulases were investigated at different concentrations, and enzymatic kinetics parameters were also determined to clarify the possible action mechanism.

\section{MATERIALS AND METHODS}

\subsection{Materials}

Cellulase I (17 U/mg (CMCase),crude enzyme used in feed additive) and cellulose II (200 U/mg (CMCase), Trichoderma reesei, purified enzyme used in laboratory) were purchased from Huamei Biochemical Company, Zhengzhou, China. Both materials were dipped in an enzyme buffer solution $(0.2 \mathrm{~mol} / \mathrm{L} \mathrm{Na}$-acetate buffer $(\mathrm{pH}$ $4.8)$ ). The enzyme concentration in the reactive system was 0.1U CMCase. Carboxymethyl cellulose (CMC, medium viscosity) was purchased from Kermel Chemical Reagent Co. Ltd., Tianjin, China. Buffer salts and other reagents were bought from commercial sources.

\subsection{Reaction System}

Various concentrations of salts in the reaction systems were prepared as follows: $\mathrm{NaCl}$ and $\mathrm{KCl}(1,10$ and 100 $\mathrm{mmol} / \mathrm{L})$, or $\mathrm{AlCl}_{3}, \mathrm{MgCl}_{2}, \mathrm{CaCl}_{2}$ and $\mathrm{CoCl}_{2}(0.05,0.1,1$, 5 , and $10 \mathrm{mmol} / \mathrm{L}), \mathrm{CoCl}_{2}(100 \mathrm{mmol} / \mathrm{L})$ and $\mathrm{Na}_{2} \mathrm{SO}_{4}$, $\mathrm{Na}_{2} \mathrm{CO}_{3}$ and $\mathrm{CH}_{3} \mathrm{COONa}(0.1,0.5$ and $1 \mathrm{~mol} / \mathrm{L})$, respectively. In the enzymatic reactions, $0.2 \mathrm{~mol} / \mathrm{L}$ of sodium acetate buffer solution ( $\mathrm{pH} 4.8$ ) was used.

\subsection{Determination of Cellulase Activity}

The cellulolytic activity of complete cellulase and activeity of endoglucanase were determined by measurement of reduced sugars in the process of enzyme reaction with filter paper (filter paper activity, FPA) or carboxymethyl cellulose (carboxymethyl cellulase activity, CMCase). FPA was determined according to the methods of Ghose [12] and Miller [13]. Briefly, Whatmen No. 1 filter paper $(50 \mathrm{mg}, 1 \mathrm{~cm} \times 6 \mathrm{~cm})$ was dipped into $0.2 \mathrm{~mol} / \mathrm{L}$ acetate buffer ( $\mathrm{pH} 4.8$ ) with various concentrations of metal ions and anions and reacted with cellulase at $50^{\circ} \mathrm{C}$ for $1 \mathrm{~h}$. The enzymes were incubated with $0.2 \mathrm{~mol} / \mathrm{L}$ acetate buffer $(\mathrm{pH} 4.8)$ for $10 \mathrm{~min}$ at $50^{\circ} \mathrm{C}$ prior to measurement of the residual activity under standard assay conditions. The reducing sugar was measured using 3, 5-dinitro- salicylic acid (DNS) reagent with glucose as a standard. One unit of activity was defined as the amount of enzyme which liberated $1 \mu \mathrm{mol}$ of reducing sugars, expressed as glucose equivalents per minute. Activity of CMCase was measured with various concentrations of metal ions and anions in $6.25 \mathrm{~g} / \mathrm{L} \mathrm{CMC}, 0.2 \mathrm{~mol} / \mathrm{L}$ acetate buffer, $\mathrm{pH} 4.8$ at $50^{\circ} \mathrm{C}$ for $30 \mathrm{~min}$ [14]. The enzymes were incubated with $0.2 \mathrm{~mol} / \mathrm{L}$ acetate buffer $(\mathrm{pH} 4.8)$ for $10 \mathrm{~min}$ at $50^{\circ} \mathrm{C}$ before measurement of the residual activity under standard assay conditions. The reducing sugar content was analyzed using the same method described above.

The relative activity was expressed as the ratio of the specific activity of the enzyme with and without metals or anions.

\subsection{Determination of Enzyme Kinetics Paramenters}

Extrapolation of the linear relationship to zero gave the initial rate to be used for determining kinetic constants for the enzyme. Maximum velocity $\left(V_{\max }\right)$ and Michaelis-Menten constant $\left(K_{m}\right)$ of the cellulase in the presence of $\mathrm{Al}^{3+}(0,2.5$ or $5.0 \mathrm{mmol} / \mathrm{L}), \mathrm{Mg}^{2+}(0,5.0$ or 10 $\mathrm{mmol} / \mathrm{L}$ ) were determined using CMC (from $6.25 \mathrm{~g} / \mathrm{L}$ to $3.125 \mathrm{~g} / \mathrm{L}$ (that is $1 /[\mathrm{S}]$ from 0.16 to 0.32 )) as substrate in $0.2 \mathrm{~mol} / \mathrm{L}$ acetate buffer $(\mathrm{pH} 4.8)$. About $0.05 \mathrm{ml}$ cellulase II (0.1U CMCase) was added and incubated at $50^{\circ} \mathrm{C}$ for $30 \mathrm{~min}$. The reducing sugar produced was measured colorimetrically with DNS reagent [9]. The $V_{\max }$ and $K_{m}$ were calculated from double-reciprocal plots according to the method of Lineweaver and Burk [15].

$$
\frac{1}{V_{o}}=\frac{K_{m}}{V_{\max }} \times \frac{1}{[S]}+\frac{1}{V_{\max }}
$$

In Equation 1 above, $V_{0}$ : enzyme reative velocity, $K_{m}$ : Michaelis-Menten constant, $V_{\max }$ : Maximum velocity, [S]: Sunstrate concentration.

\subsection{Statistical Analysis}

An analysis of variance was performed on the data using the computer program SPSS 9.0 for windows (SPSS Inc.), and Fisher's Protected Least Significant Difference Test was used at the 0.05 level to determine differences between treatment means.

\section{RESULTS AND DISCUSSION}

\subsection{Influence of Metal Ions on Cellulase Activity}

$\mathrm{Na}^{+}$and $\mathrm{K}^{+}$had a significant effect on the activity of crude cellulase at the tested concentrations although the change in relative enzyme activity was not large (from $+10 \%$ to $-10 \%$, Figure 1(a)), which was in an agreement with that reported by Mawadza et al. [8]. As shown in Figure 1(b), cellulase activity decreased at all tested 


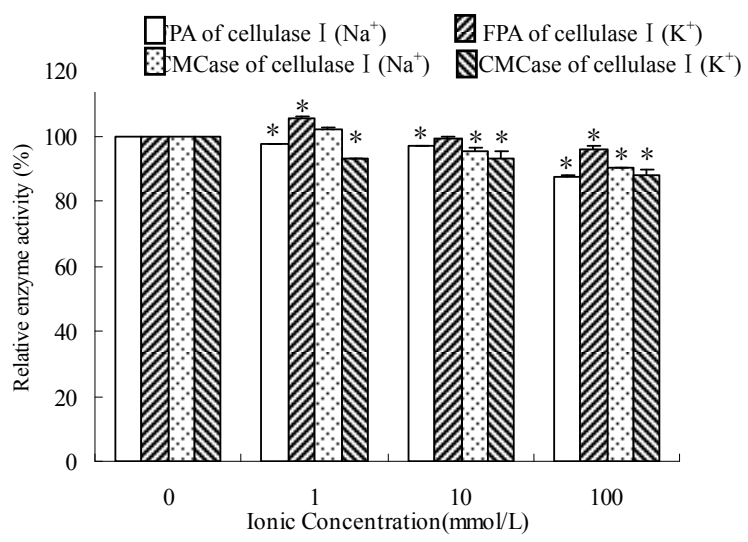

(a)

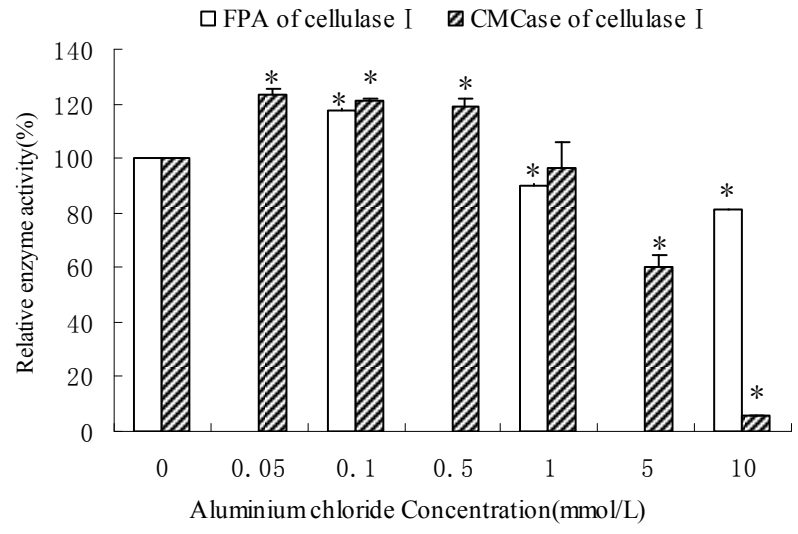

(c)

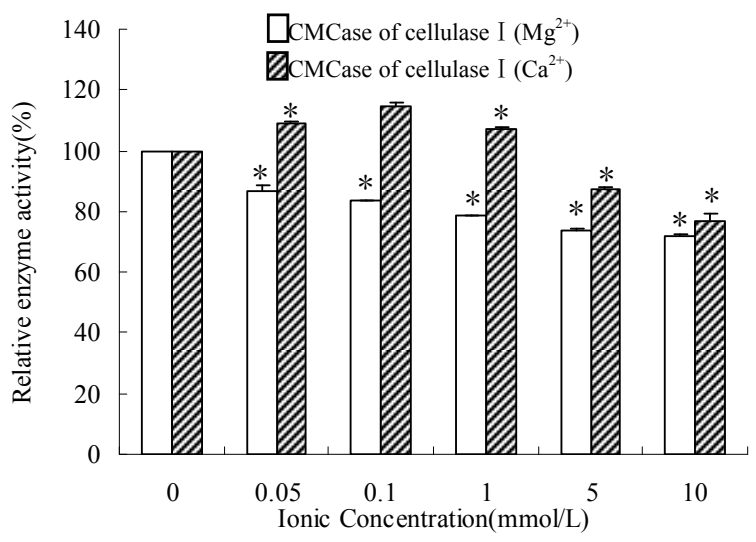

(b)

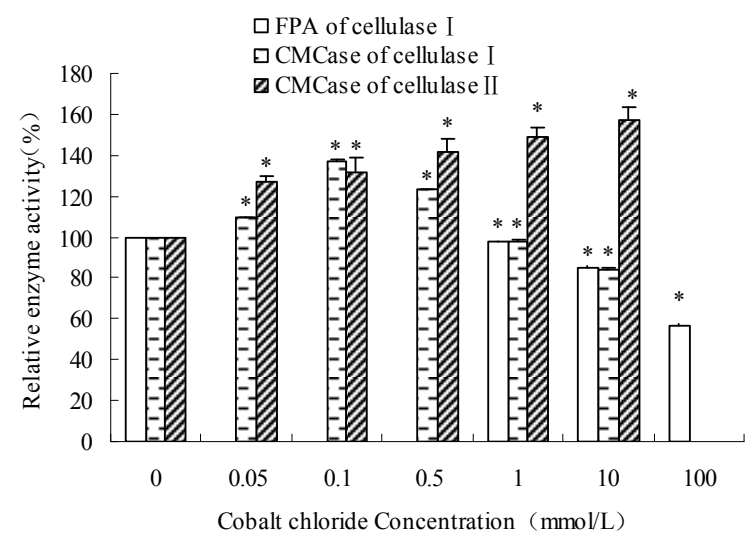

(d)

Figure 1. The influence of metal ions on two different cellulases based on CMCase activity and FPA. The enzymes were incubated in $0.2 \mathrm{~mol} / \mathrm{L}$ acetate buffer $(\mathrm{pH} 4.8)$ for $10 \mathrm{~min}$ at $50^{\circ} \mathrm{C}$ prior to measuring the residual activity under standard assay conditions. The $100 \%$ enzyme activity was obtained in absence of metal ions or acid radicals ions. (a) $\mathrm{Na}^{+}$and $\mathrm{K}^{+}$; (b) $\mathrm{Ca}^{2+}$ and $\mathrm{Mg}^{2+}$; (c) $\mathrm{Al}^{3+}$; (d) $\mathrm{Co}^{2+} ;{ }^{*}$ The mean different is significant at the 0.05 level, when compared to the $100 \%$ enzyme activity.

concentrations of $\mathrm{Mg}^{2+}$. The inhibition pattern of cellulase by $\mathrm{Mg}^{2+}$ differed from that reported by Saha [16]. The inhibition was enhanced with the increase of $\mathrm{Mg}^{2+}$ concentration. Calcium ion positively influenced the activity of cellulase at concentrations less than $1 \mathrm{mmol} / \mathrm{L}$ and negatively at more than $1 \mathrm{mmol} / \mathrm{L}$.

The cellulase activity was increased at the concentration of $\mathrm{Al}^{3+}$ below $1 \mathrm{mmol} / \mathrm{L}$ (Figure 1(c)) but enzyme activity decreased sharply when $\mathrm{Al}^{3+}$ concentration was varied from $1 \mathrm{mmol} / \mathrm{L}$ to $10 \mathrm{mmol} / \mathrm{L}$. The relative enzyme activity was only $5.7 \% \pm 0.33 \%$ at $10 \mathrm{mmol} / \mathrm{L}$ $\mathrm{AlCl}_{3}$. This indicated that the threshold of $\mathrm{Al}^{3+}$ on cellulase was $1 \mathrm{mmol} / \mathrm{L}$. Similarly, the influence of $\mathrm{Co}^{2+}$ on crude cellulase was increased at below $1 \mathrm{mmol} / \mathrm{L}$. However, unlike $\mathrm{Al}^{3+}$, the inhibition of $\mathrm{Co}^{2+}$ on cellulase was increased slowly with increasing ionic concentrations (Figure 1(d)).

The culture supernatant (crude enzyme) was found to contain a complete cellulase (endoglucanase, cellobiohydrolase, and $\beta$-glucosidase) produced by fungus, hy- drolysed cellulose to glucose, indicating that the cellulase system from the fungal strain contained all three enzymes needed for producing glucose from cellulose and had great potential to be used in enzyme saccharification of various cellulosic substrates [16]. As enzymes were purified, their specific activity increased and complete cellulase became the single enzyme composition. Cellulase enzyme systems were not merely an agglomeration of enzymes representing the three enzyme groups, but rather acted in a coordinated manner to efficiently hydrolyze cellulose [17]. The whole cellulase activity was commonly represented by FPA including synergistic actions of the three components (EG, $\mathrm{CBH}$, cellobiase) [14]. Carboxymethylcellulose (CMC) has been widely used as a substrate for studies of endoglucanase production. The single endoglucanase activity was often represented by CMCase [14]. Considering the complex action of cellulase system, this study investigated the influence of ions on cellulase based on the specific activities of two different enzymes. 
The CMCase activity of the purified cellulase (cellulase II) was not significantly affected (the relative enzyme activities ranged from $99.11 \pm 0.7 \sim 101.1 \pm 0.99 \%$ ) by natrium at the determined concentrations. The effect of $\mathrm{Na}^{+}$on cellulase was weak. The activity of cellulase were reduced only to $2 \%$ when the concentration of $\mathrm{Na}^{+}$ was varied from $1 \mathrm{mmol} / \mathrm{L}$ to $1 \mathrm{~mol} / \mathrm{L}$. Cobalt ions had significant positive effects on the CMCase for the purified cellulase (cellulase II). The effects were increased with concentration increased. The relative activity of cellulase II was $157.2 \% \pm 6.55 \%$ at $10 \mathrm{mmol} / \mathrm{L}$ of cobalt ion (Figure 1(d)). Similar result was reported by Mawadza et al. [8], but in the reverse trend was observed by Murashimaa et al. [9]. The activity of crude cellulase was increased at lower ionic concentrations and decreased at higher ones. On the other hand, results for the purified cellulase revealed that the activity of enzyme remained consistent in the presence of $\mathrm{Na}^{+}$, whereas it increased in the presence of $\mathrm{Co}^{2+}$ with increase of ionic concentration. These results might be due to different isoforms of the enzyme. During the purification the complete enzyme became single enzyme composition and the system was demineralized. There were different reactions in crude cellulase because of its complex components. The main factors were the ionic concentration and valence. There were positive correlation between the degree of inhibition and valence of metal ions. Based on the result that different metals had different effect of inhibition at the same concentration and valence $\left(\mathrm{Na}^{+} \& \mathrm{~K}^{+}\right.$, $\mathrm{Ca}^{2+} \& \mathrm{Mg}^{2+}$, Figures 1(a) and (b)), we concluded that the ionic strength had less effect than ion itself on the cellulase.

\subsection{Influence of Anions Ions on Cellulase Activity}

The activity of cellulose I decreased when anion concentration increases whereas the activity of cellulose II was little affected (Figure 2) at the similar conditions. The $\mathrm{pH}$ of the $\mathrm{CO}_{3}^{2-}$ reaction system varied from 9.59 to 11.13 , which is far from the optimum $\mathrm{pH}(4.75-6.12)$ of cellulase activity. Upon addition of $\mathrm{CH}_{3} \mathrm{COO}^{-}$and $\mathrm{SO}_{4}^{2-}$, the $\mathrm{pH}$ varied from 4.75 to 6.12 and from 4.71 to 4.89 , respectively. Higher $\mathrm{pH}$ caused enzyme deactivation. Because addition of $\mathrm{CO}_{3}^{2-}$ altered the $\mathrm{pH}$ considerably, the enzymatic activity could not be detected even if its concentration gradient was basically the same as that of $\mathrm{CH}_{3} \mathrm{COO}^{-}$. This suggested that $\mathrm{NaCO}_{3}$ might not be good for pretreatment in biomass before or at one time using cellulase. Considering the fact that the optimum $\mathrm{pH}$ of cellulase is $4.0-6.0$, the inhibition by anions might not be simply ascribed to the change in $\mathrm{pH}$ [16]. As shown in Figure 2, the inhibition of $\mathrm{CH}_{3} \mathrm{COO}^{-}$ was evident while sulfate ions had negative effects on cellulase, even if at the narrow $\mathrm{pH}$ range (from 4.71 to 4.89) and the reaction system did not change significantly. $\mathrm{Cl}^{-}$did not change $\mathrm{pH}$ of the solution but also decreased the activity of cellulase. The optimum pretreatment condition for bioconversion of lodgepole pine to ethanol was $4 \% \mathrm{SO}_{2}(\mathrm{w} / \mathrm{w})$ [18]. When wheat straw or corn stem were treated by $\mathrm{HCl}$ or $\mathrm{H}_{2} \mathrm{SO}_{4}$ the output of carbohydrate was increased with the concentration of acids, but if following with cellulase that was not. The optimum pretreatment acid concentrations were about $1 \%[11,19]$. Our experimental results might supply a reason that high concentration of anions ions inhibited cellulases activity.

\subsection{Analysis of Kinetic Properties}

The kinetic lines intersected at the same point on the

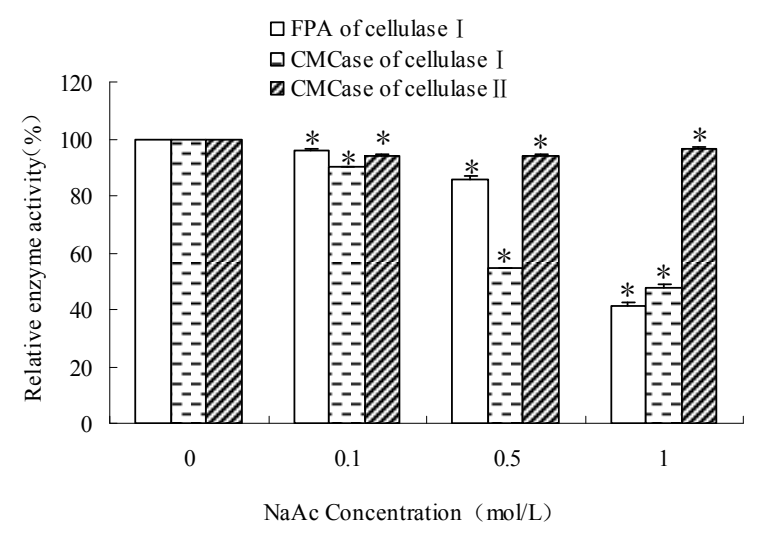

(a)

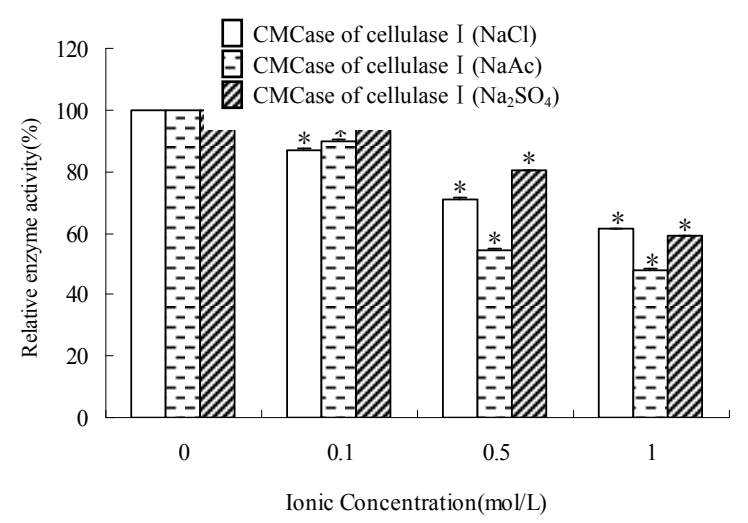

(b)

Figure 2. The influence of acid radicals ions on two different cellulases based on CMCase activity and FPA. The enzymes were incubated in $0.2 \mathrm{~mol} / \mathrm{L}$ acetate buffer $(\mathrm{pH} 4.8)$ for $10 \mathrm{~min}$ at $50^{\circ} \mathrm{C}$ prior to measuring the residual activity under standard assay conditions. The $100 \%$ enzyme activity was obtained in absence of metal ions or acid radicals ions. (a) $\mathrm{CH}_{3} \mathrm{COO}^{-}$; (b) Acid radical ions $\left(\mathrm{Cl}^{-}, \mathrm{CH}_{3} \mathrm{COO}^{-}, \mathrm{SO}_{4}^{2-}\right) .{ }^{*}$ The mean different is significant at the 0.05 level, when compared to the $100 \%$ enzyme act. 
horizontal axis, $-1 / K_{m}$. Maximum rate of reaction in the presence of $\mathrm{Al}^{3+}$ was significantly lower as compared to that without $\mathrm{Al}^{3+}$. The calculated $K_{m}$ was $22.68 \pm 0.28$ $\mathrm{g} / \mathrm{L}$ and $V_{\max }$ was $0.269 \pm 0.066 \mathrm{mg} / \mathrm{min}$ at $5.0 \mathrm{mmol} / \mathrm{L}$ of $\mathrm{Al}^{3+} ; 0.376 \pm 0.012 \mathrm{mg} / \mathrm{min}$ at $2.5 \mathrm{mmol} / \mathrm{LAl}^{3+}$; and $0.425 \pm 0.013 \mathrm{mg} / \mathrm{min}$ at $0 \mathrm{mmol} / \mathrm{LAl}^{3+}$, respectively. These data indicated that $\mathrm{Al}^{3+}$ acted as a non-competitive inhibitor for cellulase (Figure 3(a)), which might be caused by conformational changes in the enzyme structure contributed by $\mathrm{Al}^{3+}$. The kinetic lines of $\mathrm{Mg}^{2+}$ (Figure 3(b)) intersected at the same point on the vertical axis. The value of $K_{m}$ in the presence of $\mathrm{Mg}^{2+}$ was greater than those without $\mathrm{Mg}^{2+}$. The $V_{\max }$ value was approximately $0.434 \pm 0.038 \mathrm{mg} / \mathrm{min}$ in the presence of $\mathrm{Mg}^{2+}\left(K_{m}=22.74 \pm 0.412 \mathrm{~g} / \mathrm{L}\right.$ at $0 \mathrm{mmol} / \mathrm{L} \mathrm{Mg}^{2+}, 33.0 \pm$ $0.454 \mathrm{~g} / \mathrm{L}$ at $5.0 \mathrm{mmol} / \mathrm{L} \mathrm{Mg}^{2+}$, and $50.0 \pm 0.280 \mathrm{~g} / \mathrm{L}$ at $10 \mathrm{mmol} / \mathrm{L} \mathrm{Mg}^{2+}$, respectively). These data indicated that the $\mathrm{Mg}^{2+}$ acted as a competitive inhibitor of cellulase. In the presence of $\mathrm{Mg}^{2+}$ the cellulase was an apparent lower affinity for the substrate than that without $\mathrm{Mg}^{2+}$. The slope of the linear regression increased as ionic concentration increased.

Based on these results, it was evident that univalent cations $\left(\mathrm{Na}^{+}\right.$and $\left.\mathrm{K}^{+}\right)$were less influence but the divalent cations $\left(\mathrm{Ca}^{2+}\right.$ and $\left.\mathrm{Mg}^{2+}\right)$ were varying levels of influence on cellulase, even as both of them are alkaline earth metals. From the data presented in Figure 3, the kinetic character of $\mathrm{Mg}^{2+}$ was a competitive inhibitor of cellulase. Endoglucanases had two conserved glutamate residues at the active site [8]. Metal ions might bind to these residual radicals to impact on cellulase activity. $\mathrm{Mg}^{2+}$ might combine with electronegative glutamate residues reversibly binding to the active site of enzyme, leading to changes in the enzymatic catalytic activity. On the other hand, cellulase was very active during reaction with acidic and hydroxylated amino acids, except for glutamate residues. Aspartate residues were common components of cellulase structure [11]. Unlike $\mathrm{Mg}^{2+}, \mathrm{Al}^{3+}$ caused non-competitive inhibition on cellulase. In presence of $\mathrm{AlCl}_{3}$ the $V_{\max }$ value were lowered, and the $K_{m}$ value not changed compared to the control (Figure 3). In noncompetitive inhibition, the inhibitor bound to enzyme at a site other than the active site [20]. Therefore, $\mathrm{Al}^{3+}$ might increase cellulase activity by changing enzyme dimensional structure at lower concentrations. When the changes reached a certain degree, the enzyme activity might decrease substantially and result in an $\mathrm{Al}^{3+}$ threshold effect.

In summary, the activity of cellulase was increased or slightly decreased by the tested ions at concentration below $1 \mathrm{mmol} / \mathrm{L}$ of metals, and inhibited strongly at concentration above $10 \mathrm{mmol} / \mathrm{L}$ of metals and $500 \mathrm{mmol} / \mathrm{L}$ anions. Enzyme kinetic analysis indicated that $\mathrm{Mg}^{2+}$ was a competitive inhibitor and $\mathrm{Al}^{3+}$ was a noncompetitive

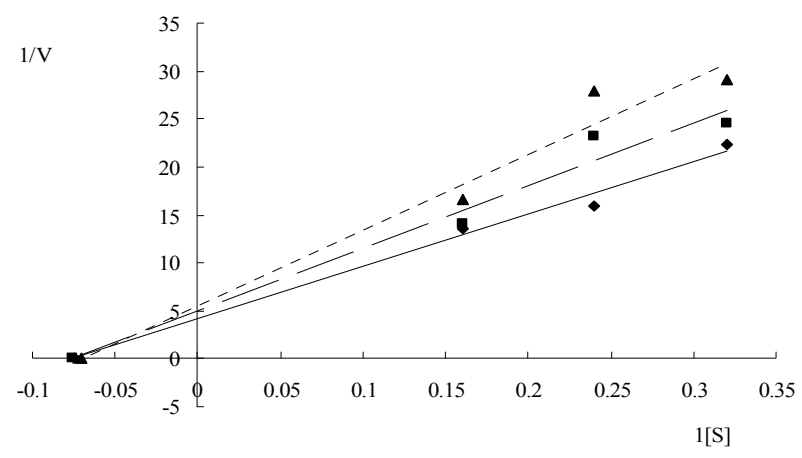

(a)

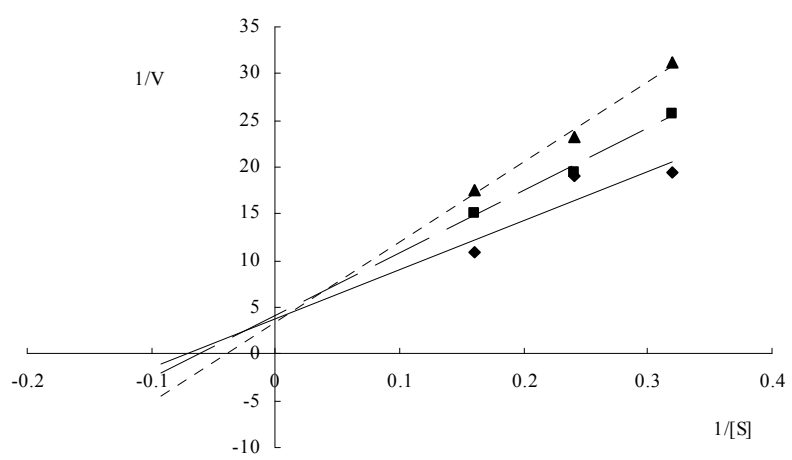

(b)

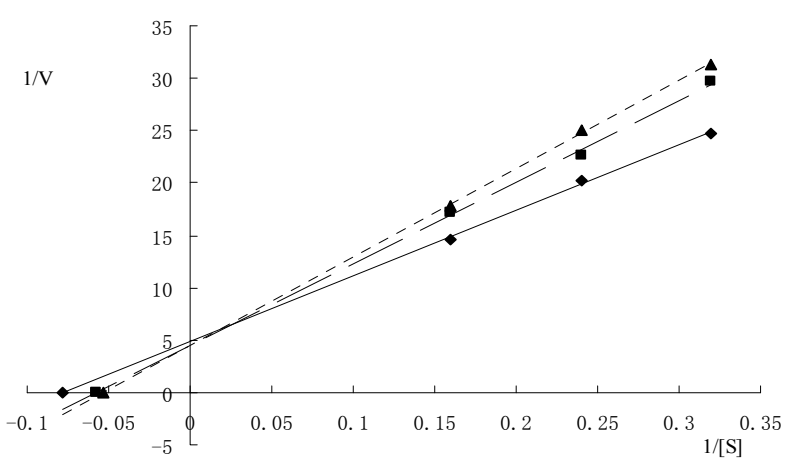

(c)

Figure 3. Kinetic analysis of cellulase hydrolyzing Carboxymethyl cellulose in the presence of several concentrations of the inhibitor at different substrate concentrations, the dosage of enzyme was invariable, measuring method was based on the analysis of CMCase. (a) Kinetic analysis of cellulase hydrolyzing $\mathrm{CMC}$ in the presence of $\mathrm{Al}^{3+}(0 \mathrm{mmol} / \mathrm{L} \square 0.25$ $\mathrm{mmol} / \mathrm{L} \Delta 0.5 \mathrm{mmol} / \mathrm{L}$ ); (b) Kinetic analysis of cellulase hydrolyzing $\mathrm{CMC}$ in the presence of $\mathrm{Mg}^{2+}\left(\begin{array}{c}\mathrm{mmol} / \mathrm{L} \\ \square\end{array}\right.$ $\mathrm{mmol} / \mathrm{L} \boldsymbol{\Delta} 10 \mathrm{mmol} / \mathrm{L}$ ); (c) Kinetic analysis of cellulase hydrolyzing $\mathrm{CMC}$ in the presence of $\mathrm{SO}_{4}^{2-}(\diamond 0 \mathrm{~mol} / \mathrm{L} \square 0.2$ $\mathrm{mol} / \mathrm{L} \Delta 0.3 \mathrm{~mol} / \mathrm{L})$.

inhibitor of cellulase, respectively. Their inhibition features were correlated with their concentrations. The inhibition produced by metal ions and anions exhibited less potent on pure enzyme than on crude one. The inhibition produced by metals with higher ionic valence was more potent on cellulase than the metals with lower ionic va- 
lence. It should be noted that the effect of metal ions and anions on activity of cellulase might vary by different detecting methods and purity of enzymes. The results indicated that FPA was a better method to estimate cellulase in enzymic saccharification of various lignocellulosic substrates. Crude cellulases should be more suitable for bioethanol industrial biodegradation of cellulosic fibers by virtue of their reaction to ions and complete enzyme.

\section{REFERENCES}

[1] Cavaco-Paulo, A. (1998) Mechanism of cellulase action in textile processes. Carbohydrate Polymers, 37, 273-237. doi:10.1016/S0144-8617(98)00070-8

[2] Azevedo, H., Bishop, D. and Cavaco-Paulo, A. (2000) Effects of agitation level on the adsorption, desorption, and activeties on cotton fabrics of full length and core domains of EGV (Humicola insolens) and CenA (Cellulomonas fimi). Enzyme and Microbial Technology, 27, 325-329. doi:10.1016/S0141-0229(00)00205-2

[3] Ito, S. (1997) Alkaline cellulases from alkaliphilic Bacillus: Enzymatic properties, genetics, and application to detergents. Extremophiles, 1, 61-66. doi:10.1007/s007920050015

[4] Ha, S.-J., Galazka, J.M., Kim, S.R., Choi, J.-H., Yang, X., Seo, J.-H., Glass, N.L., Cate, J.H.D. and Jin, Y.-S. (2011) Engineered Saccharomyces cerevisiae capable of simultaneous cellobiose and xylose fermentation. PNAS, 108, 504-509. doi:10.1073/pnas.1010456108

[5] Himmel, M.E., Ruth, M.F. and Wyman, C.E. (1999) Cellulase for commodity products from cellulosic biomass. Current Opinion in Biotechnology, 10, 358-364. doi:10.1016/S0958-1669(99)80065-2

[6] Ingram, L. and Doran, J.B. (1995) Conversion of cellulosic materials to ethanol. FEMS Microbiology Reviews, 16, 235-241. doi:10.1111/j.1574-6976.1995.tb00170.x

[7] Lloyd, T.A. and Wyman, C.E. (2005) Combined sugar yields for dilute sulfuric acid pretreatment of corn stover followed by enzymatic hydrolysis of the remaining solids. Bioresource Technology, 96, 1967-1977. doi:10.1016/j.biortech.2005.01.011

[8] Mawadza, C., Hatti-Kaul, R., Zvauya, R. and Mattiasson, B. (2000) Purification and characterization of cellulases produced by two Bacillus strains. Journal of Biotechnology, 83, 177-187. doi:10.1016/S0168-1656(00)00305-9
[9] Murashimaa, K., Nishimuraa, T. and Nakamuraa, Y. (2002) Purification and characterization of new endo-1, $4-\beta$-D-glucanases from Rhizopus oryzae. Enzyme and Microbial Technology, 30, 319-326.

[10] Clarke, A.J. and Adams, L.S. (1987) Irreversible inhibittransition metal ions. Biochimica et Biophysica Acta (BBA)_Protein Structure and Molecular Enzymology, 916, 213-219.

[11] Demain, A.L., Newcomb, M. and Wu, J.H.D. (2005) Cellulase, clostridia, and ethanol. Microbiology and Molecular Biology Reviews, 69, 124-154. doi:10.1128/MMBR.69.1.124-154.2005

[12] Ghose, T.K. (1987) Measurement of cellulase activities. Pure and Applied Chemistry, 59, 257-268. doi:10.1351/pac198759020257

[13] Miller, G.L. (1959) Use of dinitrosalicylic acid reagent for determination of reducing sugar. Analytical Chemistry, 31, 426-428. doi:10.1021/ac60147a030

[14] Zhou, X.H., Chen, H.Z. and Li, Z.H. (2004) CMCase activity assay as a method for cellulase adsorption analysis. Enzyme and Microbial Technology, 35, 455-459. doi:10.1016/j.enzmictec.2004.07.005

[15] Lineweaver, H. and Burk, D. (1934) The determination of enzy me dissociation constant. Journal of the American Chemical Society, 56, 658-666. doi:10.1021/ja01318a036

[16] Saha, B.C. (2004) Production, purification and properties of endoglucanase from a newly isolated strain of Mucor circinelloides. Process Biochemistry, 39, 1871-1876. doi:10.1016/j.procbio.2003.09.013

[17] Lynd, L.R., Weimer, P.J., van Zyl, W.H. and Isak, S. (2002) Pretorius microbial cellulase utilization: Fundamentals and biotechnology. Microbiology and Molecular Biology Reviews, 66, 506-577. doi:10.1128/MMBR.66.3.506-577.2002

[18] Ewanick, S.M., Bura, R. and Saddler, J.N. (2007) AcidCatalyzed steam pretreatment of lodgepole pine and subsequent enzymatic hydrolysis and fermentation to ethanol. Biotechnology and Bioengineering, 98, 737-746. doi:10.1002/bit.21436

[19] Yip, V.L.Y. and Withers, S.G. (2006) Breakdown of oligosaccharides by the process of elimination. Current Opinion in Chemical Biology, 10, 147-155. doi:10.1016/j.cbpa.2006.02.005

[20] McKee, T. and Mckee, J.R. (2003) Biochemistry: An introduction. 2nd Edition, McGraw-Hill Companies, Inc. and China Science Press, Beijing, 128-130. 